\title{
The Depoliticisation and 'ASEANisation' of Counter-Terrorism Policies in South-East Asia: A Weak Trigger for a Fragmented Version of Human Security
}

\author{
ALFRED GeRSTL ${ }^{1}$ \\ Society for South-East Asian Studies (SEAS), Vienna, Austria \\ ASEAS - Österreichische Zeitschrift für Südostasienwissenschaften / Austrian Journal of South-East Asian Studies \\ SEAS - Gesellschaft für Südostasienwissenschaften / Society for South-East Asian Studies - www.SEAS.at
}

This article applies a modified version of the theoretical approach of the Copenhagen School to demonstrate that the Association of Southeast Asian Nations (ASEAN) has since 2001 reacted in a twofold way to the complex political obstacles to closer counter-terrorism co-operation: First, it has responded with securitising terrorism as a transnational crime and, second, with a depoliticisation and 'ASEANisation' of its counter-terrorism policies. Depoliticisation and 'ASEANisation', i.e. the framing of a security threat under the ASEAN Way values, are both deliberate political actions. They enable politicians to base co-operation among the ASEAN members and with outside powers on a non-political, technical basis. Contradicting an assumption of the Copenhagen School, this study argues that in South-East Asia where sovereignty and noninterference are still core principles this approach can offer better political opportunities to resolve a security threat than a 'classic' securitisation. Furthermore, this article demonstrates that ASEAN's anti-terrorism policies reflect its fragmented version of human security, which is based on national and regime rather than individual security. As counter-terrorism does not enjoy political priority in the region, these policies can only be a weak trigger for the implementation of ASEAN's notion of human security

Keywords: ASEAN, Human Security, Copenhagen School, Terrorism, Counter-Terrorism Policy

Dieser Artikel wendet eine leicht modifizierte Version der Copenhagen School an, um aufzuzeigen, wie die Vereinigung südostasiatischer Nationen (ASEAN) seit 2001 auf die vielfältigen politischen Hindernisse für eine engere regionale Anti-Terrorismus-Zusammenarbeit reagiert hat. ASEAN hat, erstens, eine Sekuritisierung des Terrorismus als transnationales Verbrechen und, zweitens, eine Depolitisierung und "ASEANisierung" (die Kontextualisierung einer sicherheitspolitischen Bedrohung unter den Werten des ASEAN Way) ihrer Anti-Terrorismus-Politik vorgenommen. Sowohl Depolitisierung und "ASEANisierung" sind bewusste politische Handlungen, die es den PolitikerInnen ermöglichen, die interne wie externe Zusammenarbeit auf eine unpolitische, technische Basis zu gründen. Im Widerspruch zu einer These der Copenhagen School wird hier

1 Dr Alfred Gerstl, MIR, is scientific director of SEAS and editor-in-chief of ASEAS. His research interests include regional co-operation in East Asia and International Relations theories. Contact: alfred.gerstl@seas.at 
argumentiert, dass ein solcher Ansatz in Südostasien, wo Souveränität und Nicht-Einmischung immer noch zentrale Prinzipien sind, realpolitisch bessere Chancen eröffnen kann, um ein sicherheitspolitisches Problem zu bewältigen als eine „klassische“ Sekuritisierung. Zusätzlich zeigt der Artikel, dass ASEANs Anti-Terrorismus-Ansatz das fragmentierte Verständnis der Organisation in Bezug auf menschliche Sicherheit widerspiegelt. Dieses basiert stärker auf nationaler und Regime- als auch auf individueller Sicherheit. Da Anti-Terrorismus-Politik in der Region jedoch keine Priorität genießt, ist diese Politik bloß eine schwache Triebfeder für die Implementierung von ASEANs Verständnis von menschlicher Sicherheit.

Schagworte: ASEAN, menschliche Sicherheit, Copenhagen School, Terrorismus, Anti-TerrorismusPolitik

\section{Introduction}

Since the end of the Cold War, the South-East Asian societies have experienced a broad variety of new, non-traditional threats, be they underdevelopment, poverty, legal and illegal migration, drug and weapon smuggling, the spread of mass diseases, or terrorism (cf. Buzan, 1997; Caballero-Anthony, 2008; Dosch, 2008). Accordingly, already in the late 1980s the South-East Asian governments were gradually adopting the notion of comprehensive security (Caballero-Anthony, Emmers \& Acharya, 2006; Rüland, 2005). In South-East Asia, though, comprehensive security is a state-centric, top down rather than an individual security, bottom up approach. The Asian Financial Crisis (AFC) of 1997-98, the devastating Boxing Day tsunami of 2004, and Cyclone Nargis in 2008, however, have demonstrated that individuals can be more affected by security menaces than states. Even though the notion of security is gradually changing toward a more people-oriented understanding with human security tendencies (Caballero-Anthony, 2004; Dosch, 2008; Emmerson, 2008a, 2008b; Sukma, 2008), this article aims to show that the South-East Asian governments still view security primarily through a neorealist state- and regime-centric security lens rather than a human security prism (cf. Acharya, 2006; Caballero-Anthony, 2004; Emmerson, 2008a).

As I will further show, even though the evolving notion of more people-oriented security in South-East Asia is broad and comprehensive, it is nevertheless fragmented: The regimes and the Association of Southeast Asian Nations (ASEAN) emphasise 
the non-political dimensions of human security, e.g. socioeconomic and human development. Overall, they seem to frame security under the principles of the ASEAN Way, i.e. in the context of national and regime security rather than individual security (cf. ASEAN, 2007a). This specific framing of security can be defined as 'ASEANisation'.

This 'ASEANisation' logic applies to counter-terrorism policies in South-East Asia too. ASEAN's anti-terror approach, as I will further argue, must therefore be regarded as one means, albeit a weak means, of promoting a piecemeal version of human security that is more concerned with state than individual security. Terrorism has in parts of the region posed since the early 1990s an increasing danger to national, regime, economic, and human security alike. ASEAN, though, regards it neither as a core threat nor as a security threat alone (Ong, 2007a, p. 19; Ong K. Y., personal communication, 2 December 2008). As early as the mid-1990s ASEAN made the fight against terrorism, together with drug abuse and smuggling, a priority (ASEAN, 1997, 1999). At this time, terrorist groups in the Philippines and Indonesia were becoming increasingly transnationally active. Yet ASEAN's counter-terrorism collaboration only gained pace after the Bali bombings on 12 October 2002. The killing of 202 people, among them 88 Australians, demonstrated to the broad public the deadly transnational danger of Jemaah Islamiyah (JI), pressuring the politicians to strengthen their national and regional counter-terrorism efforts.

Yet, as I will demonstrate in this article, closer anti-terror co-operation among the ASEAN members and with outside partners still faces major obstacles, in particular differences in regard to the perception of the terrorist threat, the political will and the concrete methods to combat terrorism, and the different capabilities of the national military, policing, and law enforcement agencies (Almontre, 2003, p. 229; Dillon, 2003; Emmers, 2003, pp. 423-427; Pushpanathan, 1999; Singh, 2003, p. 217). ${ }^{2}$

Applying the theory and methodology of the constructivist Copenhagen School (Buzan, Wæver, \& de Wilde, 1998), I will argue that ASEAN, aware of the complex hindrances for closer counter-terrorism co-operation, has since the mid-1990s securitised terrorism, framing it, together with people smuggling, piracy, or money

2 Besides published works, my analysis will heavily draw on personal communications, i.e. interviews, with experts in Singapore (J Harrison., Assoc. Prof, S Rajanatnam School of International Studies, Nanyang Technological University, 1 December 2008; I Reed, Director, Economic and Political Department, US Embassy, 4 December 2008; I Storey, Visiting Fellow, Institute of Southeast Asian Studies (ISEAS), 5 December 2008, Ong KY, Ambassador and Director, Institute of Policy Studies (IPS), 2 December 2008) and Kuala Lumpur (Madya Ruhanas Harun, School of Politics \& Strategic Studies, Universiti Kebangsaan Malaysia (UKM), 8 December 2008; S Leong, Former Assistant DirectorGeneral of the Institute of Strategic and International Studies (ISIS), 9 December 2008). 
laundering, as a transnational crime. The Association has thereby diminished the political motives for terrorism (cf. Lutz \& Lutz, 2007).

Highlighting the differences between the Copenhagen School's concept of nonpoliticisation and my notion of depoliticisation, I will demonstrate that ASEAN's depoliticisation of its counter-terrorism approach offers, in combination with the 'ASEANisation' method, in fact better political opportunities to resolve a security threat than a 'classic' securitisation or a pure criminalisation (cf. Emmers, 2003). Depoliticisation and 'ASEANisation' are both deliberate political actions chosen by the ASEAN leaders. They enable them to base co-operation among the ASEAN members and with outside powers on a non-political, technical foundation. Accordingly, in the realm of counter-terrorism ASEAN's main objective is to harmonise the national and regional legal basis for bilateral and sub-regional collaboration. This political aim is not very ambitious but it is realistic as ASEAN is not a strong, independent organisation but a means for the member states to deepen their transnational cooperation.

Empirically, this study is based on an analysis of the securitisation of terrorism on regional level since the early 1990s. The securitisation process consists not only of ASEAN's 'speech acts', e.g. the Association's counter-terrorism declarations and the ASEAN Charter (ASEAN, 2007a), but of its concrete counter-terrorism policies as well.

This article starts with an analysis of the theoretical and political tensions between state, regime, and human security in South-East Asia. Subsequently, it proposes the categories of depoliticisation and 'ASEANisation' as amendments to the Copenhagen School to reconcile the theoretical conflicts. In the following chapter, ASEAN's specific anti-terror approach will be examined, focusing on its shortcomings and concrete achievements. In the conclusion, it will be demonstrated that ASEAN's counter-terrorism approach can be regarded as a driving force, albeit a weak one, for the promotion of a fragmented, 'ASEANised' notion of human security in South-East Asia. 


\section{Theoretical Framework: The Copenhagen School as Hinge Between Neorealism and Human Security}

\subsection{Securitisation, Depoliticisation and 'ASEANisation'}

Since the end of the Cold War, the Copenhagen School has broadened and deepened our traditional understanding of security, identifying new security threats that endanger new referent objects, be it the economy, society, the environment or individuals. This theory has an inherent tendency to privilege state actors in the securitisation process but also allows the securitisation of individuals and groups of individuals, making it appropriate for an analysis of human security threats. Unlike neorealism, which is mainly concerned with the security of states (and explaining the relations among them), human security is a policy-making agenda and top-down approach focussed on the security of individuals (Floyd, 2007). The neorealist perspective on state security is also poorly suited to addressing the new non-traditional hazards and explaining let alone promoting the transnationally co-operative responses they require (cf. Bellamy, 2004; Mearsheimer, 2007; Rüland, 2005). Due to its broadness and inclusive character, the transdisciplinary concept of human security is still contested and both analytically and methodically difficult to apply (Acharya, 2008; Floyd, 2007; Kerr, 2007; Peou, 2009). This holds true in particular for the broad 'freedom from want' school, which takes an all-encompassing view of human security, including human development aspects. The narrower 'freedom from fear' perspective emphasises direct violent threats to survival, be it from an authoritarian government, the police, rebels, or criminals.

Ideally, national and human security are complementary, yet there remain theoretical, analytical, and normative differences between state-centric neorealist approaches and those concerned with individual security (Kerr, 2007; UNDP, 1994). This article's notion of depoliticisation and its new category of 'ASEANisation', however, are able to bridge theoretically the Copenhagen School and neorealism to make them applicable for an analysis of human security threats.

Among the concepts developed by the Copenhagen School, the notion of securitisation is especially helpful in compensating for neorealism's somewhat narrow focus on traditional threats and inter-state relations. Many security threats 
are constructs (or at least open to interpretation) and as such are affected by political, economic, social, cultural, and historical conditions (Buzan, Wæver, \& de Wilde, 1998; Wendt, 1997). Not least among these are the perceptions and rationalisations of the governments, which remain the key actors in the securitisation process, as they possess the main "capabilities to make securitisation happen" (Floyd, 2007, p. 41). Although civil society groups play an increasingly prominent role in shaping the security discourse, due to their lack of the crucial political capabilities, their efforts are only a securitisation move. The Copenhagen School's realistic assessment of the dominance of state actors in the securitisation process is therefore in fact an analytical strength. Criticism of its analytical closeness to neorealism is thus only partly justified (cf. Booth, 2005; Williams, 2003).

A crucial amendment this article proposes to the Copenhagen School is the notion of depoliticisation - which must not be confused with the School's view of nonpoliticisation (Buzan, Wæver, \& de Wilde, 1998, p. 23). It argues that the South-East Asian securitising actors regard human security challenges as genuine security and political threats. Therefore they do not desecuritise but depoliticise it. Depoliticising a threat can objectify it in the sense that it ceases to be a subject of political discourse and is portrayed instead as a matter for expert resolution by executive order, often through means that are perceived as purely technical in nature (cf. Aras \& Karakaya Polat, 2008). Rather than stressing the human rights and democratic aspects of human security, ASEAN puts emphasis on the provision of socioeconomic development, the eradication of poverty, the implementation of long-term reforms in the economic, social and education sectors and on the requirement of an inclusive but non-political dialogue with all stakeholders (ASEAN, 2007a, 2007b; Gerstl, 2009). ${ }^{3}$ It is easier to achieve consensus for regional collaboration in matters construed as non-political, i.e. depoliticised, as they seem less imposing on sovereignty. In its depoliticised form, a policy or threat can still be part of the political and media discourse in a country.

Securitisation and depoliticisation are core categories for examining the security discourse in South-East Asia. This article agrees with Acharya (2006, p. 250) that securitisation and politicisation (or depoliticisation) cannot be regarded as "two

3 Already in the human rights debate in the early 1990s, many South-East Asian governments emphasised economic and social rights. At the World Conference on Human Rights in Vienna in 2003, Indonesia, Singapore, and China argued that political rights are a luxury that can only be afforded at a certain stage of development. Beijing also stressed the right to development - in state-dominated East Asia a right of governments, not of individuals (Tatsuo, 1999). 
neatly separate or distinct outcomes" or concepts, both are "essentially political". The same holds true for the category 'ASEANisation', introduced to take into account the political and normative regional context. Like depoliticisation, 'ASEANisation' is both a method and a deliberate political action. 'ASEANisation' is defined as the use of ASEAN values - national sovereignty, non-interference and the legitimacy of incumbent regimes - to limit the scope and sensitivity of human insecurity as a matter of discourse and policy. As the ASEAN Way has become contested in the last few years among the ASEAN members, a politically even more appropriate term is 'ASEAN-Way-framing', coined by Donald K Emmerson (personal communication, 21 December 2009). In this study, however, 'ASEANisation' remains the preferred term, referring solely to the method of framing a topic.

\subsection{The South-East Asian Security Discourse:}

State- and Regime-Centric Interpretations of Comprehensive and Human Security

The Copenhagen School's broad notion of security and referent objects that can be secured converges with the South-East Asian view - security is defined in comprehensive terms, including traditional and non-traditional threats. Yet, for an analysis of the shifting perception of security in South-East Asia, it is essential to take into account not only that security threats can be politically constructed (or at least exaggerated or downplayed) by the securitisers but also the region's state-centric security culture (Dosch, 2008, p. 74; Rüland, 2005, pp. 559-560; Smith \& Jones, 2008, p. 186).

This article claims that the governmental securitisers still regard comprehensive and human security primarily through "an established frame of reference" (Acharya, 2006, p. 249; Caballero-Anthony, 2004, pp. 160-163): neorealist state-centrism and regime legitimacy, enshrined in the ASEAN Way with its emphasis on sovereignty, non-interference and consensual decision-making. Despite the magnitude of nontraditional threats and the trend towards increased multilateralism in South-East and even North-East Asia since the early 1990s, neorealist approaches still describe the power relations and perception of security in the region very well (Bellamy, 2004; Dosch, 2008, p. 74; Rüland, 2005, pp. 559-560; Smith \& Jones, 2008, p. 186). The governments pursue power politics, based on a neorealist interpretation of politics. 
The ASEAN principles of sovereignty, territorial integrity, and non-interference in domestic affairs have enabled the regimes to pursue their nation building and socioeconomic development programs. Being the key to their legitimacy (Gerstl, 2008, p. 120), the latter are closely interlinked with security (Acharya, 2008, p. 501; cf. Dosch, 2008, p. 76). The security challenges the regimes face have therefore become increasingly complex, in particular in times of economic crises. Underdevelopment, poverty, legal and illegal migration, urbanisation, the spread of epidemics, organised crime, terrorism and environmental degradation, though, do not only threaten states but individuals.

As a policy response, the South-East Asian governments already before the end of the Cold War gradually adopted the concept of comprehensive security (CaballeroAnthony, Emmers, \& Acharya, 2006; Rüland, 2005). Though, in South-East Asia, the preponderance of sovereignty, non-interference and regime legitimacy strengthens the state-centric dimension of comprehensive and even human security (cf. CaballeroAnthony, 2004, pp. 160-163). Amitav Acharya highlights the political dimension, arguing comprehensive security was

developed and propagated by governments and the policy community in Asia (except in Japan, where the concept originated) primarily as an instrument of regime legitimization and survival, by making the governments of day appear to be seriously concerned with challenges other than military threats, primarily poverty and underdevelopment (Acharya, 2006, p. 249).

Consequently, there exist conceptual and political tensions between human and state security in South-East Asia. Insofar as a priority on human security implies an agenda that features human rights and democracy, it can clash with the preoccupation of South-East Asian regimes with their own stability, often rationalised and discursively presented as national security (Caballero-Anthony, 2004; but cf. Chandler, 2008). National and regime security, which are distinct in the developing world, are however often portrayed as inseparable by the elites in the Third World.

In retrospect, the AFC - like the SARS epidemic in 2003, the tsunami in 2004 and Cyclone Nargis in 2008 - acted as a crucial catalyst for the promotion of a more people-oriented notion of security (Emmerson, 2008b, pp. 62-64; Dosch, 2008). These incidents illustrated that communities and individual citizens can be more affected by economic, social, environmental, or political crises than the state and regime. They have also uncovered the deficiencies of ASEAN's "reactionary regionalism" (Beeson, 
2003, p. 251). In 1997, no political or economic structures existed to effectively cope with the AFC that affected major parts of East Asia. On a positive note, the crisis eventually triggered the democratisation of Indonesia, which country evolved into a leading advocate of human security.

Aware of the necessity of resolving human security threats in order to guarantee their legitimacy and of the shortcomings of the ASEAN Way for their effective resolution (ASEAN Eminent Persons Group, 2000), the ASEAN regimes announced in October 2003 their far-reaching plans for an East Asian Community by the year 2015 (initially by 2020), based on an economic, (political) security, and socio-cultural pillar (Bali Concord II). The political-security community subscribes to comprehensive security, yet highlights sovereignty and non-interference. Accordingly, the Bali Concord II (A, 2) rejects the idea of creating "a defence pact, military alliance or a joint foreign policy". The official objective, confirmed in the Vientiane Action Program (2004) and the ASEAN Charter (2007), is to transform ASEAN into a more people-oriented, inclusive, caring and sharing community.

Yet, the ASEAN Charter, signed in November 2007 and in force since December 2008, illustrates that human security still largely remains to be "found along the margins of subaltern security discourses" (Caballero-Anthony, 2004, p. 158). It falls short of promoting or even clearly defining human security (Dosch, 2008; Emmerson, 2008a). Due to the lack of consensus among the member states, it also does not unambiguously endorse democracy and human rights. The Charter reiterates the creation of the long discussed human rights body, but remains unclear about its functions (ASEAN, 2007a, Art. 14). The fifteenth ASEAN summit in Thailand in October 2009 institutionalised the ASEAN Intergovernmental Commission on Human Rights (AICHR). In the near future, though, it will resemble a tame tiger, domesticated by politicians and bureaucrats (one from each member state) rather than unleashed by civil society representatives (Ashayagachat, 2009). Consequently, South-East Asian civil right groups such as the ASEAN People's Assembly (APA) and the Solidarity for Asian People's Advocacy (SAPA) have been highly critical of these shortcomings (Collins, 2008; Dosch, 2008; SAPA, 2006).

The reason why ASEAN is so cautious in promoting human security is that this concept has a strong political and democratic connotation (Acharya, 2008; Kerr, 2007). Although its human security concept is still a work in progress (Emmerson, 2008a), it 
is likely that the organisation will in the foreseeable future further stress the statecentric and the non-political dimension, e.g. economic, social, educational, and health aspects. An illustration of the depoliticisation and 'ASEANisation' approach is Article 1, Paragraph 7 of the ASEAN Charter. It lists the strengthening of democracy and human rights among its purposes, yet under the caveat of paying "due regard to the rights and responsibilities of the Member States of ASEAN". Applying the theoretical framework of securitisation, depoliticisation and 'ASEANisation', outlined in chapter 2.1, the next part will examine whether the Association's anti-terror policies are able to promote human security - and what kind of version.

\section{ASEAN's Counter-Terrorism Policies}

\subsection{The Terrorist Threat in South-East Asia: The 'Second Front' in the 'War on Terror'}

Only after the terrorist attacks on the World Trade Center and the Pentagon on 11 September 2001 (9/11), did terrorist threats from and within South-East Asia come into the global spotlight. The Bush administration started to view the region as the 'second front' in its 'war on terror'. It feared South-East Asia with its weak states, history of political violence, high levels of poverty, and porous borders could become a safe haven or at least a region "of convenience" for al Qaeda and other terrorist groups from the Middle East, Afghanistan, and Pakistan (Abuza, 2003a, p. 135; Tay, 2003, pp. 97-98). Indeed, already in the early 1990s al Qaeda had strengthened its networks with national and local South-East Asian terrorist groups such as Jemaah Islamiyah (J) or the Moro Islamic Liberation Front (MILF) (Abuza, 2005, pp. 38-39; Acharya \& Acharya, 2007, pp. 76-78; Desker, 2003, pp. 420-423; Gunaratna, 2007, pp. 423-427; Jones, Smith, \& Weeding, 2003, pp. 444-450). All in all, over the last several years political Islam in South-East Asia has increasingly become radicalised and transnationalised (Abuza, 2003b, p. 4).

Even though terrorism has figured on ASEAN's political agenda since the mid-1990s, prior to 9/11 this threat had not promoted a deep common response. The main reason is that ASEAN was - and still is - confronted with other, more strategic challenges. Foremost among them was to prevent a possible power struggle in East Asia after the end of the Cold War. Thus the Association was keen to engage Japan and China in new multilateral structures, e.g. the ASEAN Regional Forum (ARF) and the Asia- 
Europe Meeting (ASEM) (Gerstl, 2008, pp. 121-122; Khong, 1997; Leifer, 1996). Today, a core strategic necessity for ASEAN is to engage India and the US more effectively in the regional structures and to ensure the organisation's predominance in regard to institution-building, especially as Australia and Japan have promoted their own plans for a new institutional architecture.

Only at first glance has the Bush administration's labelling of South-East Asia as the "second front" in the "war on terror" ever seemed appropriate (Gershman, 2002; Hamilton-Hart, 2005). Indeed, al Qaeda had strengthened its regional networks in the 1990s and due to its transnational and anti-Western ideology, the Indonesian J posed - and still poses - a threat to the wider region. The group aims to establish an Islamic caliphate, encompassing parts of Indonesia, Malaysia, Singapore, Brunei and the Philippines. Similar to al Qaeda, it is organised in loose, transnational networks. At the end of the 1990s, these so-called mantiqis were active even in Australia (Abuza, 2005, pp. 43-54). After 'Bali', the intensified collaboration of the Indonesian police and law enforcement agencies with their regional and Western counterparts and a new transnational focus of national counter-terrorism policies in South-East Asia in general have yielded concrete results (Chow, 2005, pp. 302-303; Jones \& Smith, 2006, p. 196; Jones, Smith \& Warding, 2003, pp. 443-444). Prominent examples are the arrest, trial, and execution of the Bali bombers in 2008 and the killing of Noordin Mohamad Top, a key JI organiser, in September 2009. The constant murder of innocent people has also eroded JI's support base (Emmerson, 2009). Internal JI disputes about the legitimacy of violence have further weakened the movement (Australian Department of Defence, 2007, pp. 35-37; Chalk \& Ungerer, 2008, p. 11;). Despite all these efforts and achievements, $J \mathrm{l}$ has managed to commit further terrorist attacks in Indonesia, e.g. on the Marriot hotel in Jakarta in 2003 or in Bali in 2004. The terrorist attacks on the Marriot and Ritz Carlton hotels in Jakarta in July 2009 illustrated once again that terrorism still imperils parts of South-East Asia.

Yet, there remain distinct differences from the 'first front'. Unlike in the Middle East or Western Asia, Islam has in South-East Asia been traditionally regarded as far more moderate. In the past, radical Middle Eastern groups struggled to popularise their rigid form of Islamism. Amitav and Arabinda Acharya (2007, p. 79) thus claim: "Southeast Asian groups would renounce violence and focus on political means as long as the end result is the establishment of an Islamic state or the implementation 
of Islamic jurisprudence." Another important difference to the Middle East is that, despite the anti-US sentiments of many South-East Asian citizens, in particular during George Bush's presidency, Washington's strategic preponderance is not contested among the political leaders. There are also no rogue states in the region that would sponsor terrorism.

Terrorism and political violence are neither a new phenomenon in South-East Asia nor have they been merely transplanted to the region by foreign groups (Chalk, Rabasa, Rosenau, \& Piggeot, 2009, p. 1). Indonesia and Vietnam fought bloody wars for their independence. After their independence, Indonesia, Malaysia, Myanmar, the Philippines and Vietnam were threatened by Communist insurgencies, and in other parts of the region militant ethno-nationalist movements and domestic religious groups were active. While during the Cold War external powers such as the Soviet Union and China actively supported Communist rebels, political violence and terrorism today have home-grown causes. Foremost among them are poverty and underdevelopment, the economic and social marginalisation of ethnic or religious minorities, weak or nonexistent public institutions, and the lack of public participation and democracy in general (Gershman, 2002, pp. 61 \& 68; International Crisis Group, 2005). ${ }^{4}$ Radical Islamism thus offers an apparent alternative for disenfranchised parts of society. However, the Malaysian government, for instance, did not respond with political reforms to minimise legitimate criticism but portrayed even moderate Islamic movements as local partners in al Qaeda's terrorist network (cf. Abuza, 2005; Gunaratna, 2005). The strict application of the Internal Security Act against terrorists and harmless regime opponents alike has been criticised by NGOs (Human Rights Watch, 2005; Humphreys, 2009; Jordan, 2009).

\subsection{Criminalisation, Depoliticisation and 'ASEANisation'}

While after 9/11 Washington's political pressure to strengthen national and regional counter-terrorism policies was a crucial external driving force for deepening ASEAN's anti-terror efforts, ${ }^{5}$ the transnational impacts of the Bali bombings in October 2002

4 According to the Freedom House Index, only Indonesia qualifies as a "free" democracy, while the Philippines, Malaysia, Singapore and Thailand are regarded as partly free, Brunei, Cambodia, Laos, Myanmar, Vietnam as not free (Freedom House, 2008; cf. Köllner, 2008).

5 In the Declaration on Joint Action to Counter Terrorism of the Heads of State or Government in November 2001, ASEAN did "unequivocally condemn in the strongest terms the horrifying terrorist attacks" of 9/11 (ASEAN, 2001a; italics in original). 
must be regarded as the main trigger (Jones \& Smith, 2006, p. 196). Prior to the terror attacks on the popular island, Jakarta denied the existence of any terrorist threats in the country (Dillon, 2003, p. 4). In general, the domestic focus of the South-East Asian police and law enforcement authorities prevailed (Jones, Smith, \& Werding, 2003, pp. 443-444). The bombings, however, illustrated to the international community the deadly danger of terrorism in South-East Asia or, to be precise, in parts of South-East Asia. Terrorism is a real threat, although, due to political interests of the regimes or other security actors, its dangers can be either exaggerated or minimised.

Crucial for the securitisation of a threat is, according to the Copenhagen School, whether the key decision-makers, e.g. politicians or the media, succeed in convincing a specific target group through a discursive 'speech act', i.e. speeches, declarations, articles, and concrete political measures (Acharya, 2006, p. 247), that a certain danger poses an existential threat to a specific referent object (Buzan, Wæver, \& de Wilde, 1998; Emmers, 2007). The latter can be the state, the regime, the economy, society, the environment, or individuals. This article, however, asserts that the securitisation conception of the Copenhagen School would not be rendered excessively vague or meaningless if it were to include non-existential threats. One reason for this is that existential threats are subjective and even relative too. A terrorist attack in the vulnerable city-state Singapore, for instance, could cause existential damage, yet this would not necessarily be the case in a megalopolis such as Jakarta. Moreover, the majority of the South-East Asian governments are authoritarian regimes, thus they do already possess extraordinary powers. Therefore, unlike in the US, the United Kingdom or Australia, there was no political need for the South-East Asian governments to discursively portray terrorism as an existential threat in order to justify new legislative measures to limit certain individual rights in the "war against terror' (cf. Wolfendale, 2007).

In the analysis of how ASEAN has securitised terrorism, this article regards the ASEAN leaders and the ministers of the interior and security affairs as the main security actors (cf. Emmers, 2003, p. 423). The 'speech act' consists of the ASEAN counter-terrorism declarations, the ASEAN Counter Terrorism Convention (ACTC), the ASEAN Charter, and speeches given by the former Secretary-General Ong Keng Yong. The referent objects that need to be secured are the state, the regime, the economy, society, and individuals (ASEAN, 2001a, 2007b). However, in the state- 
centric South-East Asian region - as in the developing world in general - the often inseparable national and regime security have political priority for the elites (Acharya, 2006; Caballero-Anthony, 2004). The target groups the ASEAN leaders needed to convince about the requirement to collectively address the severe threat of terrorism were, first, their more sceptical counterparts. Mainly the Indochinese politicians were reluctant to deepen their national and the regional anti-terror efforts, due to a different threat assessment. Secondly, in Indonesia and other countries with a large Muslim population, the politicians had to demonstrate to this audience that neither the national nor the ASEAN counter-terrorism policies in general resemble Washington's narrow and unpopular anti-terror approach. Thirdly, the ASEAN security actors had to assure the international community, notably the United States, of their commitment to the global struggle against terrorism.

The discourse analysis of ASEAN's 'speech act' since the mid-1990s shows that the ASEAN leaders have made a realistic assessment of the different threat perceptions and counter-terrorism capabilities of the member states. The declarations prove that the organisation is aware of the complex and concrete challenges terrorism presents to many South-East Asian societies. Nevertheless, ASEAN regards terrorism not as an existential but as a "profound" and "serious" threat to state, regime, economic, societal as well as international, regional and individual security (ASEAN, 2001a; 2007b). In particular Indonesia, Malaysia, Singapore, Thailand and the Philippines are endangered by terrorism and related criminal offences such as money laundering and weapons smuggling. Terrorism, however, is not a major concern for the Indochinese nations (United States Department of State Publication, 2009, ch. 2; Foot, 2008).

Consequently, as ASEAN's 'speech act' illustrates, terrorism is certainly neither a ubiquitous threat nor the core challenge ASEAN faces. In addition, the former Secretary-General Ong Keng Yong poses: "I believe that terrorism is not simply a security problem, as such it cannot be dealt with through coercive and punitive measures per se" (Chalk \& Ungerer, 2008, ch. 5; Ong, 2007a, p. 19; cf. Ong, 2007b). Yet, although terrorism might have transnational effects, it is still mostly a threat that originates within the individual member states and affects primarily the individual societies. In light of the different threat perceptions and the key ASEAN principles of sovereignty and non-interference, the ASEAN states had "great incentive to be cautious and view the problem of terrorism in term of domestic, not region wide, 
implications" (Chow, 2005, p. 320). Thus the regional counter-terrorism approach is necessarily built on the lowest common denominator and inspired by national rather than regional interests.

The political consensus ASEAN could achieve in order to deepen regional cooperation was, firstly, to securitise terrorism as a transnational crime (ASEAN, 1997, 1999, 2001a, 2004a, 2004b, 2005, 2007b, Art. II). ${ }^{6}$ Yet there was no consensus for a regional definition of terrorism. In the ACTC, ASEAN only makes references to the respective United Nations conventions, highlighting the criminal dimension of terrorism (ASEAN, 2007b, Art. Il; cf. Acharya \& Acharya, 2007, p. 75; Emmers, 2003, p. 429).

As a direct consequence of its 'ASEANisation' method - the contextualisation of a security threat or political issue under the principles of sovereignty, non-interference and regime legitimacy, ASEAN has subsequently depoliticised its anti-terrorism policies. Both depoliticisation and 'ASEANisation' (or ASEAN-Way-framing) aim to depoliticise a securitised topic, thus they must be regarded as highly political acts - a politicisation as defined by the Copenhagen School (Buzan, Wæver, \& de Wilde, 1998, ch. 2; Emmers, 2007, pp. 111-115). In the realm of counter-terrorism, a depoliticisation seems to be necessary in South-East Asia to establish an efficient framework for bi- and minilateral co-operation, both among the ASEAN members and with outside partners such as the United States and Australia (cf. Wright-Neville, 2003). Depoliticisation means that a formerly politicised issue is now primarily regarded as a security threat that is best dealt through non-political, technical measures. Contradicting the claim of the Copenhagen School, securitisation can lead under certain circumstances to a depoliticisation - and a more promising way to resolve a concrete threat. Under this non-political framework it can still be discussed in the parliament, the media, or the public in general, yet the focus lies on the concrete, technocratic methods for conflict resolution. Yet, from a normative point of view, depoliticisation and 'ASEANisation' raise serious concerns, as there is no genuine public political debate about the counter-terrorism approach.

This depoliticisation strategy is also evident in regard to ASEAN's treatment of (political) Islam. As Islam plays a regime-legitimatising role in Malaysia and Brunei,

6 In the section "Transnational Issues", the ASEAN website lists, among "Environment" and "Drugs", "Transnational Crime and Terrorism" (http://www.aseansec.org/4964.htm). 
and Muslims constitute either the majority of the population (Indonesia, Malaysia, Brunei) or at least a strong minority (Philippines, Thailand, Singapore) in certain countries, most governments also had to respond to the religious and political sensibilities of their Muslim citizens. A clear pattern in ASEAN's 'speech act' is that it stresses, in accordance with its multilateralism credo, the key role of the United Nations in the global struggle against terrorism. Another implicit criticism on the US 'war on terror' is the argument that terrorism cannot be associated with a particular culture or religion. Consequently, ASEAN recommends a broad and inclusive intrareligious and intra-cultural dialogue on a regional and global level (ASEAN, 2001a, 2002b, 2007b).

Especially after 9/11, the Bush administration has been criticised for equalling terrorism with Islam. Thus counter-terrorism collaboration with Western nations in general was regarded with distrust, possibly alienating large parts of the SouthEast Asian citizenry from their regimes (Cheng, 2006, p. 97; Tay, 2004, p. 119). This despite the fact that, initially, Washington aimed to keep a low profile, supporting its partners in capacity building and with information and intelligence sharing rather than deploying troops (Cruz De Castro, 2004, pp. 198-199; Richardson, 2001). ASEAN's counter-terrorism pact with the US from August 2002 mirrors these aims (ASEAN, 2002a). Instrumental for the closer collaboration between the US and key countries such as Indonesia and Malaysia was that America downplayed its criticism of human rights violations in South-East Asia (Grabowski, Herold, \& Jordan, 2009, pp. 197-203; Ottendörfer, 2009, p. 149).

In September 2002, however, the United States proclaimed the Bush Doctrine that stressed the "right" of the US to conduct pre-emptive strikes against alleged terrorist bases in foreign countries (The White House, 2002, pp. 15-16). This doctrine amounts to a clear violation of the principles of sovereignty and territorial integrity - and thus International Law. As large parts of the South-East Asian population became increasingly critical of the US due to the war in Iraq and the perceived anti-Muslim bias of Washington's policies in general, Jakarta and Kuala Lumpur, unlike Singapore and Manila, had to publicly downplay their increased co-operation with the US (Tay, 2004, pp. 119-123). At the end of 2003 Washington started to subscribe to ASEAN's comprehensive and less militaristic counter-terrorism approach. In general, "(t)he Bush administration's approach to Asia did not deviate significantly from the historic 
principles of U.S. Asian strategy" (Cossa et al., 2009, p. 14). However, due to the global 'war on terror', in particular the invasions of Afghanistan and Iraq, and Washington's continuing support for Israel, till the election of Barack Obama as US president in 2008 a critical perception of the US policies towards South-East Asia among the broader public prevailed (S Leong, personal communication, 9 December 2008). Under Obama, who has spent his childhood in Indonesia, the US has signed the Treaty of Amity and Cooperation (TAC) which signalled a new commitment towards multilateralism. As yet, Washington has still to fulfil its policies with concrete actions.

\subsection{Realism and Pragmatism: The Creation of a Legal Regional Framework} for Bi- and Subregional Counter-Terrorism Co-operation

Since the Bali bombings in 2002, ASEAN's process of strengthening regional counter-terrorism collaboration has become more structured and formalised. The organisation held a series of ministerial, senior diplomat, and other expert meetings to foster transnational co-operation. In this regard, the ASEAN Ministerial Meeting on Transnational Crime (AMMTC), consisting of the ministers of the interior, the chiefs of police and drug experts, played a crucial steering role.

Politically, ASEAN has since 2002 concentrated on establishing a regional, legallybased framework to harmonise the national counter-terrorism laws as base for bi- and minilateral co-operation (Millar, Rosand, \& Ipe, 2007, p. 8; Nathan, 2003, p. 256; Ong, 2007a, p. 19; Rose \& Nestorovska, 2005, p. 167;). The Philippines, Malaysia and Indonesia, for instance, have in 2002 agreed to upgrade their anti-terrorism collaboration and increase intelligence sharing; in 2003, Thailand, Cambodia and Brunei joined this mechanism (Acharya \& Acharya, 2007, pp. 83-84; Dillon, 2003). Yet Singapore, which possesses the most sophisticated counter-terrorism capabilities in the region, is still hesitant to share sensitive data with regional partners regarded as less reliable. This behaviour illustrates the need for increased confidence-building and a further depoliticisation of national counter-terrorism policies (cf. Wright-Neville, 2003, p. 6). An example for the latter is how Singapore and Indonesia deal with the spread of so-called "wrong ideologies" or a "distorted view of Islam" (Allard, 2009). Role models for the re-education of terrorists that ASEAN proposes are Singapore and Indonesia, which have implemented correction and re-education programs. In 
both countries, civil society organisations play a strong role in engaging convicted terrorists and their families and communities in a broad dialogue that also includes communal and spiritual leaders (cf. Azra, 2003, pp. 53-55; Jones, 2009).

The major achievement of ASEAN's struggle against terrorism and in the promotion of respective regional co-operation is the ASEAN Counter Terrorism Convention of 2007. The ACTC is a binding convention, although it is not yet in force. Even after a successful ratification process (so far only Singapore and Thailand have ratified it) the instruments identified in the ACTC to deepen regional co-operation, e.g. mutual legal assistance in criminal matters and even the possible extradition of terrorist suspects (Art. XIII), are not strong enough to prevent and suppress terrorist acts. Overall, Malaysia's criticism is justified: Most of the ACTC's aims and instruments only mirror provisions made in the respective UN counter-terrorism conventions. The majority of the ASEAN members, however, have not signed or ratified these conventions (Chalk \& Ungerer, 2008, p. 41). Realistically, the ACTC's focus lies once again on improving national counter-terrorism capabilities. As Zachary Abuza (2003c, p. 192) points out, "The real problem with multilateral efforts is that successful multilateralism must be built upon the foundation of a strong and effective domestic legislation and enforcement capacity". ${ }^{7}$

The areas that need to be addressed with more rigour are according to ASEAN (2007b) itself an agreement on a common list of terrorist groups and individual terrorist suspects, stricter border control mechanisms, increased regional policing, the exchange of passenger data and the prevention of counterfeiting identity papers and travel documents. Efforts to prevent the financing of terrorist groups and money laundering have also been highlighted. Notably the traditional informal Islamic money transfer system (hawala), also widespread in South-East Asia, is difficult to control (Abuza, 2003c, pp. 172-183; Ramakrishna, 2005, pp. 149-150).

Border insecurity in South-East Asia with its negative impacts on terrorism and illegal migration, in particular via Indonesia, is also a major concern for Australia. Canberra has thus further deepened its collaboration with Jakarta, providing financial support and technical advice for the Indonesian military and police as well as training for legal and financial specialists (Chalk \& Ungerer, 2008, pp. 35-42). Due to

7 To strengthen national capacities through regional training and capacity building programs is the mission of the Southeast Asian Regional Centre for Counter Terrorism (SEARCCT), established in Kuala Lumpur in 2003. Yet the SEARCCT it is still under-resourced. 
the increase in illegal immigrants from Sri Lanka and Afghanistan to Australia since 2009, the Rudd government, facing an election at the end of 2010, has strengthened its respective policing and military co-operation with Indonesia. In general, Canberra has returned under Rudd to emphasising policing in its counter-terrorism policies. The conservative Howard government preferred a hard power approach, mirroring the policies of its key ally Washington (cf. Pickering, McCulloch, \& Wright-Neville, 2008). The widespread perception of Australia as the US's deputy sheriff, however, limited Canberra's influence in South-East Asia (Cruz de Castro, 2004, p. 210).

Border security and money laundering are also challenges which the ASEAN Regional Forum aims to address. Another multilateral forum that has dealt with terrorism is the Asia-Pacific Economic Co-operation (APEC). Yet the Sydney summit in 2007 demonstrated the difficulty in getting such a politically diverse forum to implement strong common counter-terrorism measures (Gerstl, 2007, p. 87). ${ }^{8}$ A less political and more informal approach, such as that which the Bush administration has pursued, is more likely to deliver results, in particular as "some ASEAN members are worried that the West-centric counter-terrorism agenda is forcing institutional change within APEC in favour of a more legalistic, formal framework", dominated by Western norms and procedures (Ogilvie-White, 2006, p. 12).

In regard to the deepening of regional counter-terrorism efforts, ASEAN's depoliticisation strategy has been instrumental and positive. The 'ASEANisation' method has on the one hand contributed to reaching a political consensus among ASEAN members and developing specific counter-terrorism measures, while on the other hand however it has proved an impediment to a credible and strong common counter-terrorism approach. An illustration is the ACTC's strict sovereignty clause (Art. III, IV and V) that enables a regime to declare national conflicts, even with potential transnational repercussions, to be purely domestic issues, thus preventing ASEAN from intervening (cf. Helmke, 2009, p. 5). However, read in a more positive light, the ACTC is at least a political signal of a more rule-based common counterterrorism policy, although ASEAN has the power neither to enforce the ACTC norms nor to settle disputes among its members if different interpretations of the ACTC obligations arise (cf. Art. XIX). To sum up, the ACTC, emphasising state and

8 On a technical level, APEC created in 2003 a Counter Terrorism Task Force which has proved successful. It monitors the implementation of national anti-terror efforts in the realm of trade policies and provides information to member states (Rosand et al., 2008, p. 17). 
regime rather than individual security, is completely in line with ASEAN's overall understanding of comprehensive and human security.

\section{Conclusion: ASEAN's Counter-Terrorism Policies as a Trigger for an 'ASEANised' and Fragmented Version of Human Security}

Despite the increase in non-traditional threats in the last three decades, the South-East Asian governments still primarily regard the world form a neorealist point of view. Both comprehensive security and the evolving notion of a more peopleoriented understanding of security have thus been 'ASEANised'. ASEAN's counterterrorism policies reflect this state- and regime-centric view of security as well as the organisation's pragmatic, realist and voluntarist approach towards regional collaboration. In its policies, the Association does not go beyond the mandate of the member states. Even before 9/11, ASEAN was aware of the need to combat terrorism. The terror attacks on the World Trade Center and the Pentagon and in particular on the Bali nightclubs, though, were the main catalyst for a stronger anti-terror approach in South-East Asia. Due to the different threat perceptions and counterterrorism capabilities of its members as well as political sensibilities in regard to the perceived anti-Muslim bias of Washington's 'war on terror', ASEAN's anti-terrorism efforts have not been translated into a robust regional approach: the organisation could only agree to securitise terrorism as a transnational crime. Consequently, it has depoliticised and 'ASEANised' its anti-terrorism policies, thus enabling its members to co-operate on a legal-technical rather than political basis. This achievement, however, can be only a first step in a more credible approach.

At this very moment, however, ASEAN's anti-terrorism objectives may not lack vision - but ambition. In all its declarations, ASEAN basically recommends only the signing and ratification of the $16 \mathrm{UN}$ counter-terrorism conventions, the multilateral exchange of intelligence, the sharing of best practice models, and the strengthening of national police and law enforcement capabilities in general. Due to the differing levels of political will and the different capabilities to effectively combat terrorism in South-East Asia, it is highly unlikely that ASEAN will ever "qualify as an anti-terrorist coalition" (Dillon, 2003, p. 1) Therefore to allow an inner circle, notably Bangkok, 
Jakarta, Kuala Lumpur and Singapore, to co-operate in more depth with each other and outside powers (consensus minus $\mathrm{X}$ ) seems a promising concept.

In accordance with its comprehensive security view, ASEAN demonstrates in its 'speech act' that terrorism is in South-East Asia not only a security threat but in many countries reflects discontent due to underdevelopment, poverty, and a lack of education. Thus the Association acknowledges that a criminalisation of terrorism without considering the context of the problem is not sufficient to combat it. Thus, despite and precisely due to its depoliticised character, ASEAN's anti-terror policies can further trigger the notion of human security in the region, although this will also be an ASEAN-Way-framed and thus fragmented version, focused on the non-political aspects of human security. For instance, ASEAN might play down discontent with the lack of democracy and human rights as a potential cause for political violence and terrorism.

All in all, in its anti-terror declarations and the ASEAN Charter, the organisation emphasises the provision of socioeconomic development, the eradication of poverty, and the implementation of long-term reforms in the economic, social, and education sectors. ASEAN also stresses the requirement for an inclusive but non-political dialogue with all stakeholders (ASEAN, 2007a, 2007b; Ong, 2007b). Yet all these socalled people-oriented programs have a long-term focus on human development; human rights are not a major concern. Furthermore, as the Charter demonstrates, these initiatives are still primarily framed under state and regime security. ASEAN's counter-terrorism approach does therefore promote a piecemeal version of human security. However, as anti-terror politics are not the main strategic priority for ASEAN, counter-terrorism is only a weak catalyst for implementing an 'ASEANised' form of human security.

The reason for the restrictive interpretation of human security is that SouthEast governments are aware that the implementation of this concept could pose a risk to their regime stability. To depoliticise and 'ASEANise' human security might offer a short-term solution for the non-democratic regimes. Yet, due to their output logic, there is rising domestic political pressure to cope with these threats more effectively. As their civil societies have become increasingly active in promoting a more democratic and human rights agenda, it remains to be seen how long the regimes will be able to contain the unwanted democratic aspects of the human 
security concept.

To conclude, while depoliticisation seems an adequate method for the deepening of counter-terrorism co-operation in South-East Asia, it is an inappropriate means for the strengthening of human security in this region, as is 'ASEANisation'. Even though many authoritarian regimes in South-East Asia and elsewhere may not want to acknowledge it, a true state of security can only be achieved by addressing both state- and people-centred security concerns with the adoption and implemention the holistic individual and democratic spirit of the human security concept.

\section{References}

Abuza, Z. (2003a). Al Qaeda in Southeast Asia: Exploring the Linkages. In K. Ramakrishna \& S. S. Tan (Eds.) (2003), After Bali: The Threat of Terrorism in Southeast Asia (pp. 133-157). Singapore: Institute of Defence and Strategic Studies.

Abuza, Z. (2003b). Militant Islam in Southeast Asia: Crucible of Terror. Boulder, CO: Lynne Reinner.

Abuza, Z. (2003c). Funding Terrorism in Southeast Asia: The Financial Network of Al Qaeda and Jemaah Islamiya. Contemporary Southeast Asia, 25(1), 169-199.

Abuza, Z. (2005). Al-Qaeda Comes to Southeast Asia. In P. J. Smith (Ed.), Terrorism and Violence in Southeast Asia. Transnational Challenges to States and Regional Stability (pp. 38-61). Armonk, NY \& London: East Gate.

Acharya, A., \& Acharya, A. (2007). The Myth of the Second Front: Localizing the 'War on Terror' in Southeast Asia. The Washington Quarterly, 30(4), 75-90.

Acharya, A. (2006). Securitization in Asia: Functional and Normative Implications. In M. CaballeroAnthony, R. Emmers, \& A. Acharya (Eds.), Non-traditional Security in Asia: Dilemmas in Securitisation (pp. 247-250). London: Ashgate.

Acharya, A. (2008). Human Security. In J. Baylis, S. Smith, \& P. Owens (Eds.), The Globalization of World Politics. An introduction to international relations (4th ed., pp. 491-505). Oxford, UK: Oxford University Press.

Allard, T. (2009, September, 19/20). Battle won but war continues: Yudhoyono. Sydney Morning Herald, p. 16.

Alkire, S. (2003). A Conceptual Framework for Human Security. (Centre for Research on Inequality, Human Security and Ethnicity Working Paper 2). University of Oxford.

Almontre, J. T. (2003). Enhancing State Capacity and Legitimacy in the Counter-Terror War. In K. Ramakrishna \& S. S. Tan (Eds.), After Bali: The Threat of Terrorism in Southeast Asia (pp. 221-240). Singapore: Institute of Defence and Strategic Studies. 
Aras, B., \& Karakaya Polat, R. (2008). From Conflict to Cooperation: Desecuritization of Turkey's Relations with Syria and Iran. Security Dialogue, 39(5), 475-495.

ASEAN Eminent Persons Group. (2000). Report of the ASEAN Eminent Persons Group (EPG) on Vision 2020 The People's ASEAN. Jakarta, Indonesia: ASEAN Secretariat.

Ashayagachat, A. (2009, 25 October). A difficult birth for Asean human rights. Bangkok Post. Retrieved 25 October 2009, from http://www.bangkokpost.com/opinion/opinion/26234/a-difficult-birth-forasean-human-rights

Australian Department of Defence. (2007). Australia's National Security. A Defence Update. Canberra, Australia.

Azra, A. (2003). Bali and Southeast Asian Islam: Debunking the Myths. In K. Ramakrishna \& S. S. Tan (Eds.), After Bali: The Threat of Terrorism in Southeast Asia (pp. 39-57). Singapore: Institute of Defence and Strategic Studies.

Bellamy, A. J. (2004). The Pursuit of Security in Southeast Asia: Beyond Realism. In M. Beeson (Ed.), Contemporary Southeast Asia. Regional Dynamics, National Differences (pp. 156-177). Houndsmills, UK: Palgrave MacMillan.

Booth, K. (Ed.). (2005). Critical Security Studies and World Politics. Boulder, CO: Lynne Rienner.

Buzan, B. (1997). Rethinking Security after the Cold War. Cooperation and Conflict, 32(1), 5-28.

Buzan, B., \& Wæver, O. (2003). Regions and powers: the structure of international security. Cambridge, UK \& New York: Cambridge University Press.

Buzan, B, Wæver, O., \& de Wilde, J. (1998). Security: A New Framework for Analysis. Boulder, CO: Lynne Rienner.

Caballero-Anthony, M. (2004). Re-visioning Human Security in Southeast Asia. Asian Perspective, 28 (3), 155189.

Caballero-Anthony, M. (2008). Challenging Change: Nontraditional Security, Democracy, and Regionalism. In D. K. Emmerson (Ed.), Hard Choices: Security, Democracy and Regionalism in Southeast Asia (pp. 191-217). Stanford, CA: Stanford University Shorenstein APARC.

Caballero-Anthony, M., Emmers, R., \& Acharya, A. (Eds.). (2006). Non-traditional Security in Asia: Dilemmas in Securitisation. London: Ashgate.

Chalk, P., \& Ungerer, C. (2008). Neighbourhood watch. The evolving terrorist threat in Southeast Asia. Australian. Sydney: Strategic Policy Institute (ASPI).

Chalk, P., Rabasa, P. Rosenau, W. \& Piggeot, L. (2009). The Evolving Terrorist Threat to Southeast Asia. A Net Assessment. Santa Monica, CA, Arlington, VA, \& Pittsburgh, PA: Rand.

Cheng, J. Y. S. (2006). Broadening the Concept of Security in East and Southeast Asia: the impact of the Asian financial crisis and the September 11 Incident. Journal of Contemporary China, 15(46), 89-111.

Chow, J. T. (2005). ASEAN Counterterorrism Cooperation since 9/11. Asian Survey, 45(2), 302-321.

Collins, A. (2008). A People-Oriented ASEAN: A Door Ajar or Closed for Civil Society Organizations? Contemporary Southeast Asia, 30(2), 313-331. 
Cossa, R. A., Glosserman, B., MacDevitt, M. A., Patel, N., Przystup, J. \& Roberts, B. (2009). The United States and the Asia-Pacific Region: Security Strategy for the Obama Administration. Washington, DC: National Defence University.

Cruz De Castro, R. (2004). Addressing International Terrorism in Southeast Asia. Contemporary Southeast Asia, 26(2), 193-217.

Desker, B. (2003). Islam in Southeast Asia: The Challenge of Radical Interpretations. Cambridge Review of International Affairs, 16(3), 415-428.

Dillon, D. R. (2003). The Shape of Anti-Terrorist Coalitions in Southeast Asia. Heritage Lectures, Nr 773.

Emmers, R. (2003). ASEAN and the securitization of transnational crime in Southeast Asia. The Pacific Review, 16(3), 419-438.

Emmers, R. (2007). Securitization. In A. Collins (Ed.), Contemporary Security Studies (pp. 109-125). Oxford, UK: Oxford University Press.

Emmerson, D. K. (Ed.). (2008a). Hard Choices: Security, Democracy and Regionalism in Southeast Asia. Stanford, CA: Stanford University Shorenstein APARC.

Emmerson, D. K. (2008b). Critical Terms: Security, Democracy, and Regionalism in Southeast Asia. In D. K. Emmerson (Ed.), Hard Choices: Security, Democracy and Regionalism in Southeast Asia (pp. 3-56). Stanford, CA: Stanford University Shorenstein APARC.

Emmerson, D. K. (2009, July 23). Contexts of terror in Indonesia. Asia Times. Retrieved 12 October 2009, from http://www.atimes.com/atimes/Southeast_Asia/KG23Ae01.html

Foot, R. (2008). Framing Security Agendas: U.S. Counterterorrist Policies and Southeast Asian Responses (Policy Studies No. 49). Washington, DC: East-West Center.

Freedom House (2008). Freedom in the World 2008. Table Combined Average Ratings: Independent Countries, 2008. Washington. Retrieved 21 September 2009, from http://www.freedomhouse.org/ template.cfm?page $=25 \&$ year $=2008$

Gasper, D. (2005). Securing Humanity: Situating "Human Security" as Concept and Discourse. Journal of Human Development, 6(2), 221-245.

Gershman, J. (2002). Is Southeast Asia the Second Front? Foreign Affairs, 81(4), 60-74.

Gerstl, A. (2007). Vom Multilateralismus zum Bilateralismus: Das APEC-Treffen in Sydney im September 2007. ASEAS - Austrian Journal of South-East Asian Studies, 1(1), 86-90.

Gerstl, A. (2008). The China Factor in Regional Security Cooperation: The ASEAN Regional Forum and the Shanghai Cooperation Organization. ASEAS - Austrian Journal of South-East Asian Studies, 1(2), 73-99.

Gerstl, A. (2009). ASEAN im Krieg gegen den Terror: Sekuritisierung, Kriminalisierung, "ASEANisierung” und Depolitisierung des Terrorismus. In M. Grabowski, H. Herold, \& R. Jordan (Eds.), Sicherheit kontra Menschenrechte. Antiterrorpolitik in Asien (pp. 161-183). Bad Honnef, Germany: HorlemannVerlag.

Grabowski, M., Herold, H., \& Jordan, R. (Eds.). (2009a). Sicherheit kontra Menschenrechte. Antiterrorpolitik in Asien (pp. 161-186). Bad Honnef, Germany: HorlemannVerlag. 
Grabowski, M., Herold, H., \& Jordan, R. (2009b). Sicherheit kontra Menschenrechte. Kritische Analysen zur Antiterrorpolitik in Asien. In M. Grabowski, H. Herold, \& R. Jordan (Eds.), Sicherheit kontra Menschenrechte. Antiterrorpolitik in Asien (pp. 187-203). Bad Honnef, Germany: HorlemannVerlag.

Gunaratna, R. (2005). Understanding al-Qeada and Its Network in Southeast Asia. In P. J. Smith (Ed.), Terrorism and Violence in Southeast Asia. Transnational Challenges to States and Regional Stability (pp. 6276). Armonk, NY \& London: East Gate.

Gunaratna, R. (2007). Terrorism in Southeast Asia - Threat and Response. In G. Chaliand \& A. Blin (Eds.), The History of Terrorism. From Antiquity to al Qaeda (pp. 420-434). Berkeley, CA, Los Angeles, CA, \& London: University of California Press.

Hamilton-Hart, N. (2005). Terrorism in Southeast Asia: expert analysis, myopia and fantasy. The Pacific Review, 18(3), 303-325.

Helmke, B. (2009). The Absence of ASEAN: Peacekeeping in Southeast Asia. Pacific News, 31, 4-6.

Human Rights Watch. (2005). Detained Without Trial. Abuse of Internal Security Act Detainees in Malaysia. New York: Human Rights Watch.

Humphreys, A. (2009). Continuity in a Changing World: Malaysia's Coercive Security Apparatus in the Age of Terror and Beyond. ASEAS - Austrian Journal of South-East Asian Studies, 2(2), 70-97.

International Crisis Group. (2005, May 18). Southern Thailand: Insurgency, Not Jihad. (Asia Report No. 98).

International Crisis Group. (2007, May 3). Indonesia: Jemaah Islamiyah's Current Status. (Asia Briefing No. 63).

Jane's World Insurgency and Terrorism. (2008, November 6). Southern Thai Separatist Groups.

Jones, D. M., \& Smith, M. L. R. (2006). ASEAN and East Asian International Relations. Regional Delusion. Cheltenham \& Northampton, UK: Edward Elgar.

Jones, D. M., Smith, M. L. R., \& Weeding, M. (2003). Looking for the Pattern: Al Qaeda in Southeast Asia - The Genealogy of Terror Network. Studies in Conflict \& Terrorism, 26(6), 443-457.

Jones, S. (2009, July 16). Prison Reform Can Counter Terror Risks. The Age.

Jordan, R. (2009). Gegen Kommunisten und Terroristen. In M. Grabowski, H. Herold \& R. Jordan (Eds.), Sicherheit kontra Menschenrechte. Antiterrorpolitik in Asien (pp. 127-143). Bad Honnef, Germany: HorlemannVerlag.

Kerr, P. (2007). Human Security. In A. Collins (Ed.), Contemporary Security Studies (pp. 91-108). Oxford, UK: Oxford University Press.

Khong, Y. F. (1997). Making bricks without straw in the Asia Pacific? Review article. The Pacific Review, 10(2), 289-300.

Köllner, P. (2008). Autoritäre Regime in Asien: Allgemeine Trends und jüngere Entwicklungen (GIGA Focus Asien No.12). Hamburg, Germany: GIGA.

Leifer, M. (1996). The ASEAN Regional Forum: Extending ASEAN's Model of Regional Security (Adelphi Paper No. 302). Oxford, UK \& London: Oxford University Press and International Institute for Strategic Studies. 
Millar, A., Rosand, E., \& Ipe, J. (2007). Implementing the United Nations General Assembly's Global CounterTerrorism Strategy in the Asia-Pacific. Washington, DC: Center on Global Counter-Terrorism Cooperation.

Nathan, K. S. (2003). Counter-Terror Cooperation in a Complex Security Environment. In K. Ramakrishna \& S. S. Tan (Eds.), After Bali: The Threat of Terrorism in Southeast Asia (pp. 241-258). Singapore: Institute of Defence and Strategic Studies.

Ogilvie-White, T (2006). Non-proliferation and Counterterrorism Cooperation in Southeast Asia: Meeting Global Obligations through Regional Security Architectures? Contemporary Southeast Asia, 28(1), 1-26.

Ong, K. Y. (2007a). Advancing Multilateral Efforts in Counter Terrorism and Security in Southeast Asia. Military Technology, 12, 18-23.

Ong, K. Y. (2007b). Keynote Speech. At the Security Forum Asia "Advancing Multilateral Efforts in Counter Terrorism and Security in Southeast Asia". Kuala Lumpur, 25-27 June 2007. Retrieved 12 October 2009, from http://www.aseansec.org/20701.htm

Ottendörfer, E. (2009). Ein hart umkämpftes Gut. Die Stellung der Menschenrechte in Indonesiens Kampf gegen den Terrorismus. In M. Grabowski, H. Herold, \& R. Jordan (Eds.), Sicherheit kontra Menschenrechte. Antiterrorpolitik in Asien (pp. 144-160). Bad Honnef, Germany: HorlemannVerlag.

Pickering, S., McCulloch, J., \& Wright-Neville, D. (2008). Counter-Terrorism Policing: Community, Cohesion and Security. New York: Springer.

Peou, S. (2009). Introduction: Collaborative action problems in human security. In S. Peou (Ed.), Human Security in East Asia: Challenges for collaborative action (pp. 61-76). New York: Routledge.

Pushpanathan, S. (1999). Combatting Transnational Crime in ASEAN. Paper presented at the $7^{\text {th }}$ ACPF World Conference on Crime Prevention and Criminal Justice, November 23-26, 1999. New Delhi, India. Retrieved 25 September 2009, from http://www.aseansec.org/2823.htm

Ramakrishna, K. (2005). Countering Radical Islam in Southeast Asia: The Need to Confront the Functional and Ideological 'Enabling Environment'. In P. J. Smith (Ed.), Terrorism and Violence in Southeast Asia. Transnational Challenges to States and Regional Stability (pp. 145-168). Armonk, NY \& London: East Gate.

Richardson, M. (2001, November 1). America`s War on Terror Ends Years of Indifference to Region: US Woos Southeast Asian Allies. International Herald Tribune, p 1.

Rosand, E., Millar, A., Ipe, J., \& Healey, M. (2008). The UN Global Counter-Terrorism Strategy and Regional and Subregional Bodies: Strengthening a Critical Partnership. Washington, DC: Center on Global CounterTerrorism Cooperation.

Rose, G., \& Nestorovska, D. (2005). Towards an Asean Counter-Terrorism Treaty. Singapore Year Book of International Law, 9, 157-190.

Rüland, J. (2005). The Nature of Southeast Asian Security Challenges. Security Dialogue, 36(4), 545-563.

Singh, B. (2008). Singapore: Success at Home, Challenges from Abroad. Southeast Asia Affairs, 1, 315-330.

Singh, D. (2003). ASEAN Counter-Terror Strategies and Cooperation: How effective? In K. Ramakrishna \& S. S. Tan (Eds.), After Bali: The Threat of Terrorism in Southeast Asia (pp. 201-220). Singapore: Institute of Defence and Strategic Studies. 
Smith, P. J. (Ed.). (2005). Terrorism and Violence in Southeast Asia. Transnational Challenges to States and Regional Stability. Armonk, NY \& London: East Gate.

Sucharithanarugse, W. (2000). The concept of 'human security' extended: 'Asianizing' the paradigm. In W. Tow, R. Thakur \& I.-T. Hyun (Eds.), Asia's Emerging Regional Order (pp. 49-61). Tokyo: United Nations University.

Sukma, R. (2008). Political Development: A Democracy Agenda for ASEAN? In D. K. Emmerson (Ed.), Hard Choices: Security, Democracy and Regionalism in Southeast Asia (pp. 135-149). Stanford, CA: Stanford University Shorenstein APARC.

Tan, A. (2003). The Indigenous Roots of Conflict in Southeast Asia: The Case of Mindanao. In K. Ramakrishna \& S. S. Tan (Eds.), After Bali: The Threat of Terrorism in Southeast Asia (pp. 97-113). Singapore: Institute of Defence and Strategic Studies.

Tan, A., \& Boutin, K. (Eds.). (2001). Non-traditional Security Issues in Southeast Asia. Singapore: Institute of Defence and Strategic Studies.

Tay, S. S. G. (2004). Asia and the United States after 9/11: Primacy and Partnership in the Pacific. Fletcher Forum of World Affairs, 28(1), 113-132.

The White House. (Ed.) (2002). The National Security Strategy of the United States of America. Washington, DC: The White House.

United Nations Development Program (Ed.). (1994). Human Development Report 1994. New York \& Oxford, UK: Oxford University Press.

United States Department of State Publication. Office of the Coordinator for Counterterrorism. (2009, April). Country Reports on Terrorism 2008. Washington, DC.

Wendt, A. (1999). Social Theory of International Politics. Cambridge, UK: Cambridge University Press.

Williams, M. C. (2003). Words, Images, Enemies: Securitization and International Politics. International Studies Quarterly, 47(4), 511-532.

Wolfendale, J. (2007). Terrorism, Security, and the Threat of Counterterorrism. Studies in Conflict $\mathcal{E}$ Terrorism, 30(1), 75-92.

\section{ASEAN COMMUNIQUES}

ASEAN. (1997). ASEAN Declaration on Transnational Crime. Manila, 20 December. Retrieved 24 October 2009, from http://www.aseansec.org/5985.htm

ASEAN. (1999). Joint Communique of the Second ASEAN Ministerial Meeting on Transnational Crime (AMMTC). Yangon, 23 June. Retrieved 14 October 2009, from http://www.aseansec.org/5632.htm

ASEAN. (2001a). 2001 ASEAN Declaration on Joint Action to Counter Terrorism Bandar Seri Begawan, 5 November. Retrieved 24 October 2009, from http://www.aseansec.org/5620.htm

ASEAN. (2001b). Joint Communique of the Third ASEAN Ministerial Meeting on Transnational Crime (AMMTC). Singapore, 11 October. Retrieved 11 October 2009, from http://www.aseansec.org/5621.htm 
ASEAN. (2002a). ASEAN-United States of America Joint Declaration for Cooperation to Combat International Terrorism, Bandar Seri Begawan, 1 August. Retrieved 24 October 2009, from http://www. aseansec.org/10574.htm

ASEAN. (2002b). Joint Communique of the Special ASEAN Ministerial Meeting on Terrorism, Kuala Lumpur, 20-21 May. Retrieved 24 October 2009, from http://www.aseansec.org/5618.htm

ASEAN (2003). Declaration of ASEAN Concord II (Bali Concord II). Bali, 7 October. Retrieved 24 October 2009, from http://www.aseansec.org/15159.htm

ASEAN. (2004a). Joint Communique of the Fourth ASEAN Ministerial Meeting on Transnational Crime (AMMTC), Bangkok, 8 January. Retrieved 12 October 2009, from http://www.aseansec.org/15649.htm

ASEAN. (2004b). Joint Communique of the First ASEAN Plus Three Ministerial Meeting on Transnational Crime (AMMTC+3), Bangkok, 10 January. Retrieved 11 October 2009, from http://www.aseansec. org/15645.htm

ASEAN. (2005). Joint Communique of the Fifth ASEAN Ministerial Meeting on Transnational Crime (AMMTC), Hanoi, 29 November. Retrieved 11 October 2009, from http://www.aseansec.org/17938.htm

ASEAN. (2007a). The ASEAN Charter. Jakarta, Indonesia: ASEAN Secretariat. Retrieved 24 October 2009, from http://www.aseansec.org/ASEAN-Charter.pdf

ASEAN. (2007b). ASEAN Counter Terrorism Convention (ACCT). Retrieved 12 October 2009, from http:// Www.aseansec.org/19251.htm

ASEAN. (2007c). Joint Communique of the Third ASEAN Plus Three Ministerial Meeting on Transnational Crime (AMMTC+3), Bandar Seri Begawan, 7 November. Retrieved 12 October 2009, from http://www. aseansec.org/21042.htm

ASEAN. (2008). Joint Communique of the 28th ASEAN Chief of Police Conference. Brunei Darussalam, 25-29 May. Retrieved 21 October 2009, from http://www.aseansec.org/21620.htm 